\title{
Effect of Bauhinia holophylla treatment in Streptozotocin-induced diabetic rats
}

\author{
MARCELO S. PINHEIRO ${ }^{1}$, LUHARA S. RODRIGUES ${ }^{1}$, LEILA S. NETO ${ }^{1}$, RAFAIANNE \\ Q. MORAES-SOUZA ${ }^{1}$, THAIGRA S. SOARES ${ }^{1}$, MADILEINE F. AMÉRICO ${ }^{1}$, KLEBER \\ E. CAMPOS ${ }^{1}$, DÉBORA C. DAMASCENO ${ }^{2}$ and GUSTAVO T. VOLPATO ${ }^{1,2}$
}

\footnotetext{
${ }^{1}$ Laboratório de Fisiologia de Sistemas e Toxicologia Reprodutiva, Instituto de Ciências Biológicas e da Saúde, Universidade Federal de Mato Grosso/ UFMT, Av. Valdon Varjão, 6390, 78600-000 Barra do Garças, MT, Brazil

${ }^{2}$ Laboratório de Pesquisa Experimental de Ginecologia e Obstetrícia, Faculdade de Medicina de Botucatu, Universidade Estadual Paulista/ UNESP, Distrito de Rubião Jr, s/n, 18618-970 Botucatu, SP, Brazil
}

Manuscript received on January 27, 2016; accepted for publication on November 28, 2016

\begin{abstract}
Bauhinia holophylla, commonly known as "cow's hoof", is widely used in Brazilian folk medicine for the diabetes treatment. Therefore, the aim of this study was at evaluating the aqueous extract effect of Bauhinia holophylla leaves treatment on the streptozotocin-induced diabetic rats. Diabetes was induced by Streptozotocin $(40 \mathrm{mg} / \mathrm{Kg})$ in female Wistar rats. Oral administration of aqueous extract of Bauhinia holophylla leaves was given to non-diabetic and diabetic rats at a dose of $400 \mathrm{mg} / \mathrm{kg}$ during 21 days. On day 17 of treatment, the Oral Glucose Tolerance Test was performed to determine the area under the curve. At the end of the treatment, the animals were anesthetized and blood was collected for serum biochemical parameters analysis. After treatment with Bauhinia holophylla extract, non-diabetic and diabetic rats presented no glycemic changes. On the other hand, the plant treatment decreased body weight and increased ALT and AST activities. In conclusion, the treatment with aqueous extract of $B$. holophylla leaves given to diabetic rats presented no hypoglycemic effect in nondiabetic animals and no antidiabetic effect in diabetic animals with the doses studied. In addition, the diabetic animals treated with the B. holophylla extract showed inconvenient effects and its indiscriminate consumption requires particular carefulness.
\end{abstract}

Key words: Bauhinia holophylla, diabetes, lipid profile, medicinal plants, rats.

\section{INTRODUCTION}

Diabetes mellitus is the name given to a group of disorders with different etiologies. It is characterized by disarrangements in carbohydrates, proteins and fat metabolism caused by complete or partial insufficiency of insulin secretion and/or insulin action (ADA 2016, Reece et al. 2004).

Several drugs are used to control diabetes, however, perfect glucose control is rarely achieved

Correspondence to: Prof. Dr. Gustavo Tadeu Volpato

E-mail: gtvolpato@yahoo.com
(Cooppan 2005). Moreover, plants have been used as an alternative therapy for the diabetes treatment. Many plants present hypoglycemic activity, which were demonstrated experimentally in animals and humans, but some still require further investigation (Volpato et al. 2002, Damasceno and Volpato 2008). Although several plants were tested for diabetes treatment, many of them were not evaluated, including species of the genus Bauhinia, popularly known as "cow's hoof" (Lorenzi and Matos 2002). These species typically present a wide distribution 
in tropical regions such as Asia, Africa and South America, so they have adapted well to the Brazilian climate (Donato 1995). Also, the biological properties of different preparations of Bauhinia spp. were investigated in in vitro and in vivo studies and their results encouraged the hypothesis of a hypoglycemic activity (Cechinel Filho 2009). Some attempts were made to attribute the antidiabetic effects of the leaf extracts to the kaempferitrin, the major flavonoid derivative (Pinheiro et al. 2006). Several studies showed the hypoglycemic effect of Bauhinia forficata (Silva et al. 2002, Pepato et al. 2004, Lino et al. 2004, Frankish et al. 2010), then other species of the same genus may have similar effect by the phylogenetic and chemistry proximity. Chemotaxonomy in conjunction with phylogenetic analysis may provide novel insights into species delimitation and chemical ecology (Kim et al. 2016).

Bauhinia holophylla (Leguminosae) is one of the species of Bauhinia used as antidiabetic. There are no studies in the literature to evaluate the hypoglycemic potential effect of $B$. holophylla. Our hypothesis is that this medicinal plant may have a beneficial result on hyperglycemic status, preventing the diabetic repercussions. Therefore, the aim of this study was at evaluating the aqueous extract effect of $B$. holophylla leaves treatment on the streptozotocin-induced diabetic rats.

\section{MATERIALS AND METHODS}

\section{EXTRACTION OF PLANT MATERIALS}

The Bauhinia holophylla leaves were collected in Barra do Garças, Mato Grosso State, Brazil, between April and May 2013, in the morning period. The plant was identified and authenticated from the Botanic Department of Federal University of Mato Grosso (UFMT), where a voucher specimen (UFMT 05718) was left. Their leaves were dried at $50^{\circ} \mathrm{C}$ for a period of $24 \mathrm{~h}$ in an aerated stove, ground and a powder was prepared, similarly to the folk-medicine preparation method. B. holo- phylla aqueous extract was prepared by boiling 1 liter (L) of water for 5 minutes (min) and adding 70 grams $(\mathrm{g})$ of the powder. The extract was agitated and covered until it reached room temperature. The residue was removed by filtration and the extract was then suitably concentrated in a rotary evaporator. A sample was separated for determination of the solid concentration, and the extract was divided into aliquots stored at $-20^{\circ} \mathrm{C}$ until further use.

\section{EXPERIMENTAL ANIMALS}

Female Wistar rats (200-230 g), approximately 90 days old, were obtained from the UFMT Vivarium and were maintained under standard laboratory conditions $\left(22 \pm 3^{\circ} \mathrm{C}, 12\right.$-h light/dark cycle), with pelleted food (Purina rat chow, Purina ${ }^{\circledR}$, São Paulo, SP, Brazil) and tap water ad libitum. The procedures and animal handling were performed in accordance with the guidelines provided by the Brazilian College of Animal Experimentation in agreement with the International Guiding Principles for Biomedical Research Involving Animals promulgated by the Society for the Study of Reproduction and were authorized by the Ethical Committee for Animal Research of the UFMT, Brazil (protocol number 23108.001989/13-0).

After two weeks of acclimatization, the diabetes was induced in rats with Streptozotocin (STZ, Sigma Chemical Company ${ }^{\circledR}$, St. Louis, Millstone). STZ was intravenously (i.v.) administered in a dose of $40 \mathrm{mg} / \mathrm{Kg}$ dissolved in citrate buffer $(0.1$ $\mathrm{M}, \mathrm{pH}$ 6.5). Control rats received i.v. citrate buffer. Blood glucose concentrations were measured by One Touch Ultra glucometer (Johnson \& Johnson ${ }^{\circledR}$ ) seven days after diabetes induction, and glucose concentrations exceeded $300 \mathrm{mg} / \mathrm{dL}$ confirmed the diabetic state (Damasceno et al. 2012).

\section{EXPERIMENTAL GROUPS}

After diabetic state was confirmed, the rats were placed in four experimental groups ( $\mathrm{n}=11$ animals/ 
group): Control - rats treated with vehicle (water); Treated Control - rats treated with $B$. holophylla extract; Diabetic - diabetic rats treated with vehicle; and Treated Diabetic - diabetic rats treated with B. holophylla extract. The treatment dose of 400 $\mathrm{mg} / \mathrm{Kg} /$ day of the $B$. holophylla extract was orally given by gavage during 21 days. Body weight, water and food intake and blood glucose were also evaluated weekly in the morning period.

\section{BIOCHEMICAL PROFILE ANALYSIS}

Oral glucose tolerance test (OGTT) was performed at day 17 of treatment. After an overnight fasting of 12 hours, a glucose solution $(200 \mathrm{~g} / \mathrm{L})$ was administered into the stomach of the rats through a gastric catheter, at a final dose of $2 \mathrm{~g} / \mathrm{Kg}$ body weight. The treated groups also received the plant extract 15 min. before glucose administration. Blood glucose concentrations were measured at 0 (previous administration of glucose solution/plant extract fasting glucose), 30, 60 and $120 \mathrm{~min}$ (Mello et al. 2001, Sinzato et al. 2012). Glucose responses during the OGTT were evaluated by estimation of the total area under the curve (AUC), using the trapezoidal method (Tai 1994).

At day 21 of treatment, the rats were anesthetized by sodium pentobarbital (Tiopentax ${ }^{\circledR}-50 \mathrm{mg}$ / $\mathrm{Kg}$ ) and blood samples were collected by decapitation for biochemical determinations. The blood samples were collected and put into anticoagulantfree test tubes, maintained in ice for $30 \mathrm{~min}$ and then centrifuged at $1300 \times \mathrm{g}$ during $10 \mathrm{~min}$ at $4{ }^{\circ} \mathrm{C}$. The supernatant was collected as serum and stored at $-80^{\circ} \mathrm{C}$ for further determination of biochemical parameters.

Serum concentrations of total protein (TP) was determined colorimetric method, and total cholesterol (CHO), triglycerides (TG), highdensity lipoprotein (HDL-c) concentrations; and also alanine aminotransferase (ALT) and aspartate aminotransferase (AST) activities were estimated by enzymatic method (Young 2000) by Winner ${ }^{\circledR}$ assay kits. The values were expressed in milligrams per deciliter (mg/dL). Very-low-density lipoprotein (VLDL) serum level estimated value was calculated through the triglyceride concentrations (Knopfholz et al. 2014).

\section{STATISTICAL EVALUATION}

Analysis of variance (ANOVA) followed by Tukey's Multiple Comparison test was used to compare mean values. Differences were considered statistically significant when $p<0.05$.

\section{RESULTS}

As shown in Figure 1, blood glucose levels presented near $100 \mathrm{mg} / \mathrm{dL}$ in control groups. In the diabetic groups, glucose levels were higher than $300 \mathrm{mg} / \mathrm{dL}$. The treatment with $B$. holophylla aqueous extract did not interfere significantly with the glycaemia of control or diabetic groups compared with their corresponding groups.

The animals of control and treated groups showed no difference in body weight, water and food intake during the study. The body weight in diabetic groups was statistically lower compared to control on days 14 and 20. In addition, the plant treatment caused a reduction in the body weight compared to the diabetic group (non-treated) on days 14 and 20. The rats from diabetic groups presented higher food intake (around $30 \mathrm{~g} /$ day) in relation to control groups (about $16 \mathrm{~g}$ /day) in all experimental period. In addition, the average water intake was increased in diabetic groups as compared to non-diabetic groups (Table I).

Figure 2 a shows the glycemic curve of the oral glucose tolerance test of control groups and Figure $2 \mathrm{~b}$ of diabetic groups. The rats in both diabetic groups presented statistically higher blood glucose levels in relation to those of control animals throughout the test. The non-treated groups showed the glycemic curve with a similar pattern with increasing glucose levels at 30 minutes com- 
pared to time 0 , and returning to the basal level at the time 120 in both groups (control and diabetic). The blood glucose levels of diabetic animals treated with the plant presented no significant statisti- cally difference between all timepoints measured (Figure 2b).

The control groups showed an area under the curve around 14,000 mg/dL/120 minutes. The rats

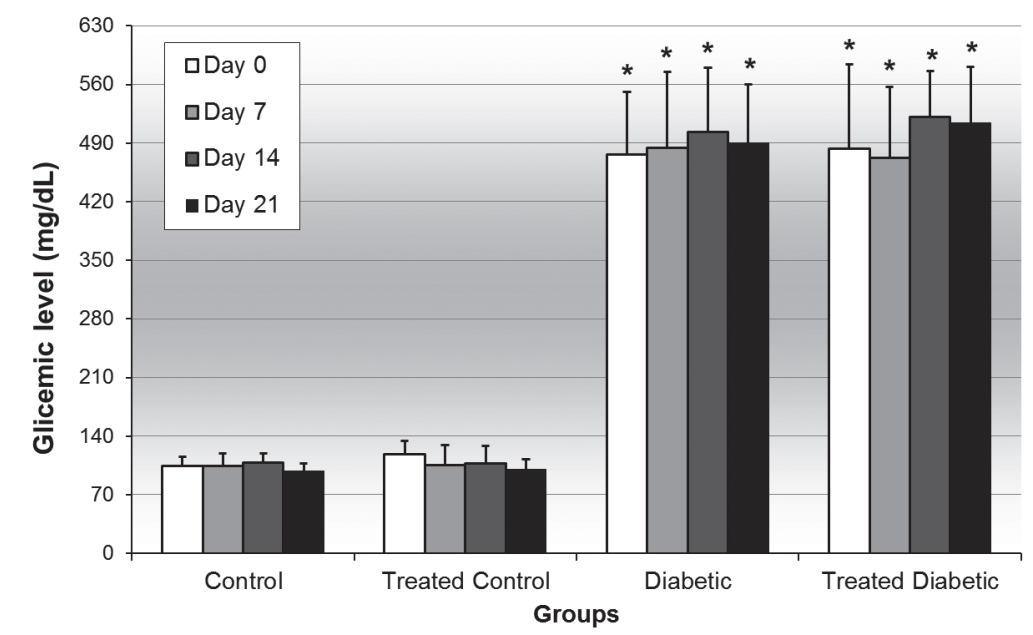

Figure 1 - Blood glucose levels on days 0,7,14 and 21 of the control and diabetic rats treated or not with a Bauhinia holophylla aqueous extract $(400 \mathrm{mg} / \mathrm{Kg})$ during 21 days of experiment. Data shown as mean \pm standard deviation. $* \mathrm{p}<0.05$ compared control group (ANOVA followed Tukey's multiple comparison test).

\section{TABLE I}

Body weight, water intake and food intake on days 0, 7, 14 and 21 of the control and diabetic rats treated or not with a Bauhinia holophylla aqueous extract $(400 \mathrm{mg} / \mathrm{Kg})$ during 21 days of experiment.

\begin{tabular}{|c|c|c|c|c|}
\hline & \multicolumn{4}{|c|}{ Groups } \\
\hline & Control & Treated Control & Diabetic & Treated Diabetic \\
\hline \multicolumn{5}{|c|}{ Body weight (g) } \\
\hline Day 0 & $249.7 \pm 22.1$ & $251.0 \pm 21.7$ & $243.6 \pm 19.3$ & $232.8 \pm 17.7$ \\
\hline Day 7 & $255.0 \pm 18.5$ & $245.0 \pm 20.3$ & $232.5 \pm 17.9$ & $213.4 \pm 26.5^{*}$ \\
\hline Day 14 & $253.9 \pm 15.9$ & $243.0 \pm 22.6$ & $230.6 \pm 19.6^{*}$ & $210.4 \pm 24.6^{* \#}$ \\
\hline Day 20 & $255.8 \pm 16.1$ & $241.5 \pm 19.0$ & $230.9 \pm 22.4^{*}$ & $208.1 \pm 20.8^{* \#}$ \\
\hline \multicolumn{5}{|c|}{ Water intake (mL) } \\
\hline Day 0 & $39.1 \pm 8.0$ & $36.5 \pm 5.3$ & $114.6 \pm 49.2 *$ & $99.1 \pm 53.4^{*}$ \\
\hline Day 7 & $35.5 \pm 6.1$ & $36.0 \pm 6.7$ & $117.9 \pm 55.0^{*}$ & $115.7 \pm 55.3^{*}$ \\
\hline Day 14 & $34.6 \pm 5.7$ & $35.8 \pm 6.5$ & $138.9 \pm 44.1^{*}$ & $124.1 \pm 45.9 *$ \\
\hline Day 20 & $35.5 \pm 4.7$ & $35.2 \pm 6.4$ & $146.4 \pm 45.5^{*}$ & $125.5 \pm 47.5^{*}$ \\
\hline \multicolumn{5}{|c|}{ Food intake (g) } \\
\hline Day 0 & $17.6 \pm 3.9$ & $16.1 \pm 2.8$ & $23.6 \pm 7.2$ & $24.6 \pm 8.7$ \\
\hline Day 7 & $17.3 \pm 3.3$ & $17.6 \pm 3.1$ & $26.9 \pm 8.3^{*}$ & $25.1 \pm 4.8^{*}$ \\
\hline Day 14 & $17.1 \pm 2.2$ & $16.7 \pm 2.5$ & $32.1 \pm 7.4 *$ & $30.2 \pm 8.9 *$ \\
\hline Day 20 & $16.6 \pm 2.0$ & $16.9 \pm 3.6$ & $35.4 \pm 8.5^{*}$ & $28.9 \pm 8.1^{*}$ \\
\hline
\end{tabular}

Data shown as mean \pm standard deviation (SD). * $\mathrm{p}<0.05$ compared to control group (ANOVA followed Tukey's multiple comparison test). ${ }^{\#} \mathrm{p}<0.05$ compared to diabetic group (ANOVA followed Tukey's multiple comparison test). 

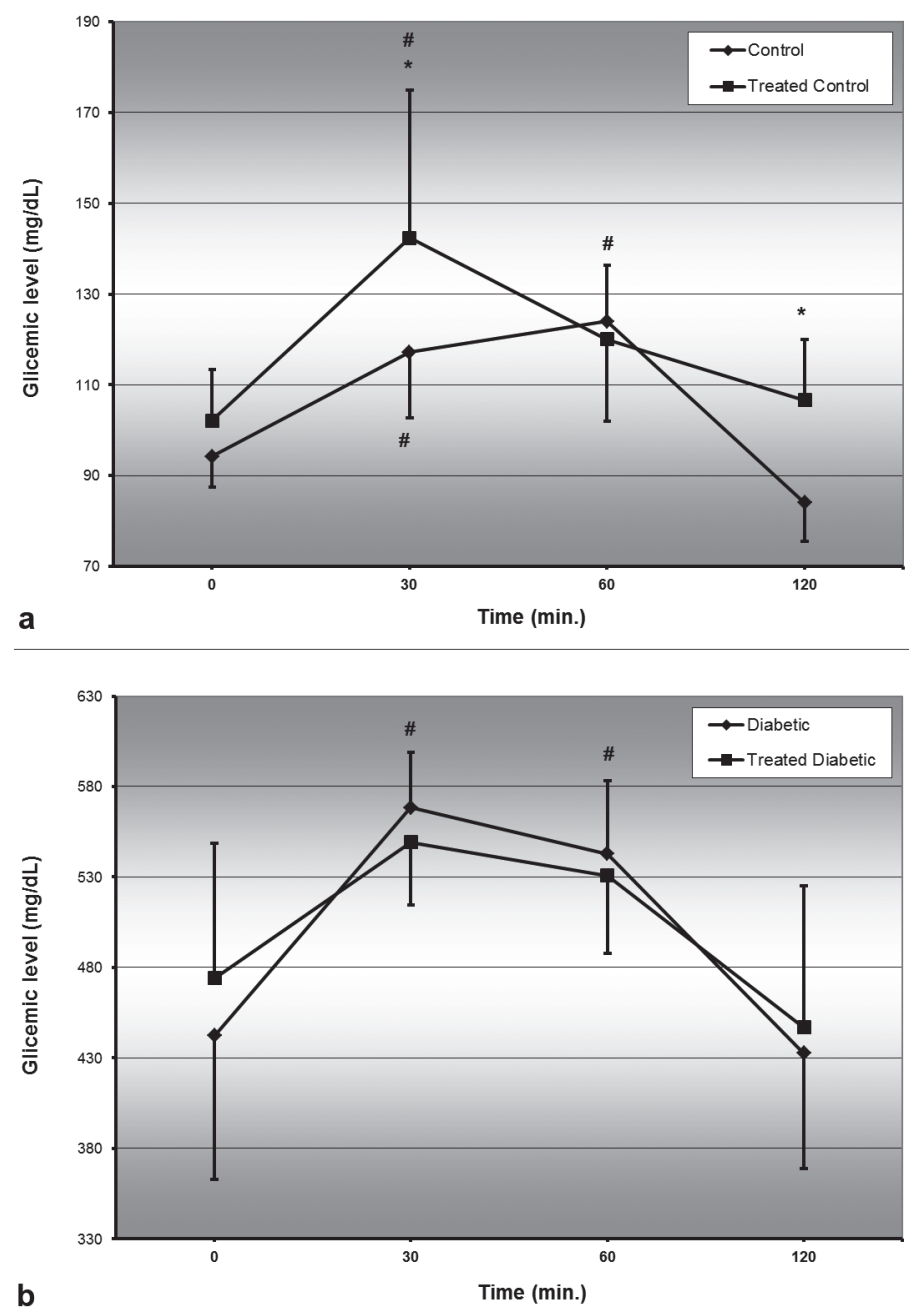

Figure 2 - Oral glucose tolerance test on the day 17 of treatment of control (a) and diabetic (b) rats treated or not with a Bauhinia holophylla aqueous extract $(400 \mathrm{mg} / \mathrm{Kg})$ during 21 days of experiment. Data shown as mean \pm standard deviation (SD). $* \mathrm{p}<0.05$ compared to control group (ANOVA followed Tukey' $\mathrm{s}$ multiple comparison test). ${ }^{\#} \mathrm{p}<0.05$ compared to Time 0 (ANOVA followed Tukey's multiple comparison test).

from diabetic groups showed an area under the curve higher compared to control groups, reaching approximately $60,000 \mathrm{mg} / \mathrm{dL} / 120$ minutes. The $B$. holophylla extract treatment did not change data about area under the curve as compared to the untreated diabetic group (Figure 3).

As shown in Table II, the treated control group presented HDL-cholesterol values decreased as compared to those of control group. The diabetic group presented higher levels of serum total proteins in relation to those of control group. Both diabetic groups showed higher levels of triglycerides, total cholesterol, VLDL-cholesterol concentrations, and also ALT and AST activities compared to those of control group. The treated diabetic group showed decreased HDL-cholesterol levels as compared to those of the control and diabetic groups. In addition, the plant treatment caused increased ALT and AST activities in diabetic animals compared to diabetic group. 


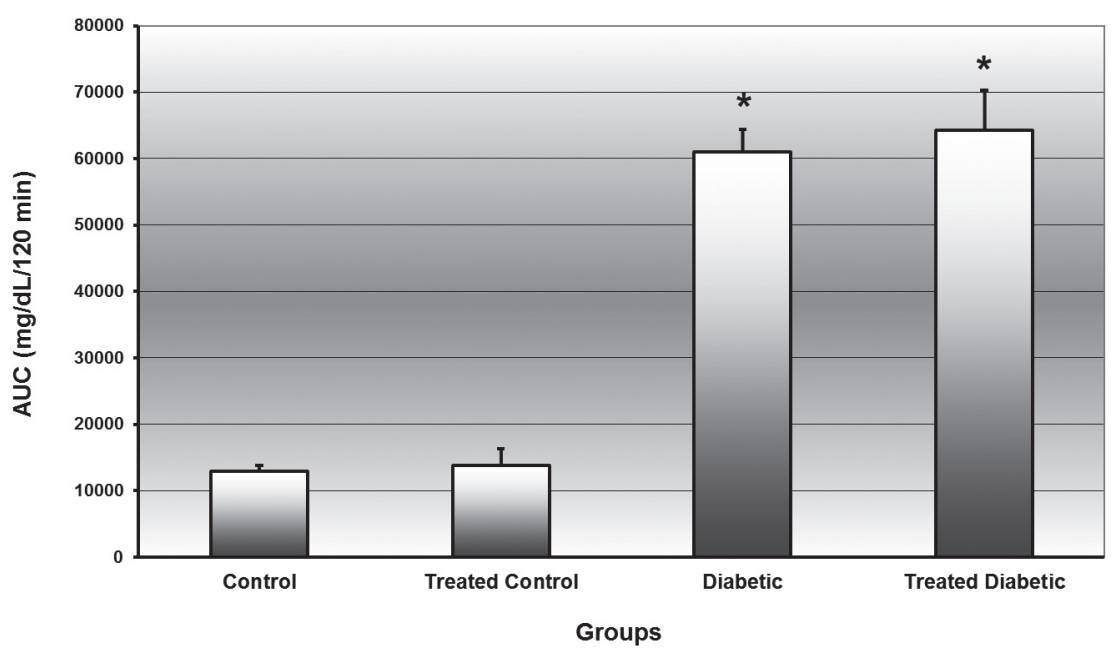

Figure 3 - Area under the curve (AUC) in the day 17 of treatment of control and diabetic rats treated or not with a Bauhinia holophylla aqueous extract $(400 \mathrm{mg} / \mathrm{Kg})$ during 21 days of experiment. Data shown as mean \pm standard deviation. ${ }^{*} \mathrm{p}<0.05$ compared control group (ANOVA followed Tukey's multiple comparison test).

TABLE II

Biochemical parameters of control and diabetic rats treated or not with a Bauhinia holophylla aqueous extract (400 mg/Kg) during 21 days of experiment.

\begin{tabular}{lcccc}
\hline & \multicolumn{3}{c}{ Groups } \\
\cline { 2 - 5 } & Control & Treated Control & Diabetic & Treated Diabetic \\
\hline Total protein (g/dL) & $4.3 \pm 0.4$ & $4.3 \pm 0.2$ & $5.0 \pm 0.3^{*}$ & $4,7 \pm 0,7$ \\
Triglycerides (mg/dL) & $91.8 \pm 27.3$ & $120.0 \pm 36.3$ & $593.3 \pm 358.6^{*}$ & $797.7 \pm 104.3^{*}$ \\
Cholesterol (mg/dL) & $81.1 \pm 6.7$ & $77.5 \pm 13.7$ & $113.0 \pm 20.4^{*}$ & $107.7 \pm 13.9^{*}$ \\
HDL (mg/dL) & $60.4 \pm 8.2$ & $26.9 \pm 2.1^{*}$ & $61.9 \pm 10.2$ & $40.2 \pm 5.7^{* \#}$ \\
VLDL (mg/dL) & $18.3 \pm 5.5$ & $24.0 \pm 7.3$ & $118.7 \pm 71.7^{*}$ & $159.5 \pm 20.9^{*}$ \\
ALT (U/l) & $78.2 \pm 12.1$ & $54.5 \pm 13.9$ & $186.7 \pm 93.2^{*}$ & $390.0 \pm 52.0^{* *}$ \\
AST (U/l) & $196.6 \pm 29.6$ & $180.0 \pm 42.6$ & $327.6 \pm 146.3^{*}$ & $981.0 \pm 151.3^{* *}$ \\
\hline
\end{tabular}

Data shown as mean \pm standard deviation (SD). * $\mathrm{p}<0.05$ compared to control group (ANOVA followed Tukey's multiple comparison test) ${ }^{\#} \mathrm{p}<0.05$ compared to diabetic group (ANOVA followed Tukey's multiple comparison test).

\section{DISCUSSION}

The estrogen affects the glucose and lipoprotein metabolism. Studies demonstrated that uncontrolled hyperglycemia, hypertension and dyslipidemia is more common in women than male with diabetes (Göbl et al. 2010, Mascarenhas-Melo et al. 2013). This fact explains our choice for females to evaluate the hypoglycaemic effect of $B$. holophylla. These rats entered in the experimental design with 90 days old. In the first day of treatment, the rats were with 120 days old (adulthood). Sengupta (2013) reported that the females rats become sexually mature at 6 weeks (40 days old), and adulthood period begins after the eighth week of post-natal life ( $\sim 60$ days old), confirming that the female rats used in this study were also adult.

In our laboratory, previous studies showed no alteration on blood glucose level of rats treated with $200 \mathrm{mg} / \mathrm{Kg}$ of the $B$. forficata aqueous extract, which is a traditional dose of this medicinal herbal used by the population (Volpato et al. 1999). Pepato et al. (2002) also showed that acute treatment with B. forficata decoction produced no alteration in 
glycemic levels under to 31 days. Contradictorily, several authors demonstrated hypoglycemic effect of Bauhinia species extract or fraction. In addition, some species even has showed insulin mimetic properties and hypoglycemic action, for example $B$. variegata (Silva et al. 2002, Pepato et al. 2004, Lino et al. 2004, Frankish et al. 2010). Rozza et al. (2015) verified that Bauhinia holophylla hydroalcoholic extract $(150 \mathrm{mg} / \mathrm{Kg})$ enhanced glutathione peroxidase (GSH-Px) and glutathione reductase (GR) activities and the reduced glutathione (GSH) level, suggesting an antioxidant activity from $B$. holophylla. In our study, B. holophylla treatment did not interfere in blood glucose levels of the diabetic and it causes no hypoglycemia in non-diabetic rats. This might be justified due to administered dose, extraction method, short treatment period, and the sensitivity difference among the plants used and the animals tested (Campos et al. 2009), which would prevent the effective action by the plant extract. Another variable to consider is the type of diabetes studied. Streptozotocin is known to reproduce the severe diabetes (glycemia above $300 \mathrm{mg} / \mathrm{dL}$ ), and the plant extract could be more efficient treating individuals with a moderate diabetes (glycemia between 120 and $300 \mathrm{mg} / \mathrm{dL}$ ). Previous studies testing plant extracts confirmed that animals with severe diabetes also presented no antidiabetic effect (Volpato et al. 2007, 2008, 2011).

The body weight loss represents one of the most common signs of diabetes. Despite the increased appetite, insulin deficiency reduces all anabolic processes and accelerates catabolic processes, contributing further to body weight loss, which is already occurring by glycosuria and polyuria (ADA 2014). This status was showed in this study, since treated animals from both diabetic groups showed body weight loss, especially in the last days of treatment. The B. holophylla treatment of diabetic animals led to a decreased body weight, possible due to a toxic effect of the plant in an impaired organism.
The exaggerated appetite, another physiological dysfunction caused by diabetes, is a symptom due to glucose loss in the urine at least in part, which deprives the body of a considerable part of the calories ingested with food (Kahn et al. 2005). Large quantities of glucose are eliminated through the urine, elevating the osmotic pressure and reducing water reabsorption in the renal tubules. Due to this increased diuresis, there is excessive water intake by subject via stimulation of the thirst center in hypothalamus (Powers and D'Alessio 2011). The increase in water and food consumption in diabetes was confirmed in our study, and B. holophylla treatment did not contribute to improve these disorders.

The blood glucose data generated from the OGTT shows that in non-diabetic rats the insulin uptake follows the expected physiological response, with blood glucose levels returning to its original state at the timepoint $120 \mathrm{~min}$, characterizing a glycemic return (Campos et al. 2007). However, in non-diabetic rats treated with the plant, blood glucose level returned to the initial value already at the timepoint $60 \mathrm{~min}$, which might indicate an increase in insulin release and action, resulting in a faster glucose uptake. The blood glucose level in the OGTT of diabetic rats showed that there was no reduction of the response time or the blood glucose levels of these rats. It is important to consider the diabetes type studied in this experiment. In the present study, the rats presented glycemia similar to uncontrolled human type 1 diabetes, since the Streptozotocin has a beta-cytotoxic action (Tancrede et al. 1983), leading to abnormal/lacking insulin secretion. Since there was no change in the area under the curve of Streptozotocin-induced diabetic rats, we suggest that the plant extract did not contribute to reduce the blood glucose levels.

In diabetic individuals, the lack of insulin causes inhibition of protein synthesis and increased degradation, which increases amino acid levels in the blood to be subsequently used for gluconeogenesis (Abu-Lebdeh and Nair 1996). Our study 
showed that $B$. holophylla treatment caused a reduction on the serum protein level.

In the present study, the lipid profile of diabetic rats was abnormal as expected for diabetic patients. The triglycerides, total cholesterol and VLDLcholesterol levels were higher as compared to the nondiabetic rats due to the action of lipase, whose activity is exacerbated in individuals with reduced glucose utilization. According to Umrani and Goyal (2002), the streptozotocin-induced diabetic animals presented a decreased insulin levels, increased triglycerides, and total cholesterol levels, corroborating with our results. Therefore, the $B$. holophylla treatment also causes no changes in these biochemical parameters. Some studies showed a biological tendency of the HDL-cholesterol level to accompany the total cholesterol levels (Kiss et al. 2006, Turner et al. 2004). Our results showed reduced HDL-cholesterol levels in treated groups, which might indicate metabolic changes in the liver as a result of treatment, either due to reduction in its production or its function.

The ALT and AST enzymes are found mainly in the hepatocytes, and when high levels are detected, it is possible to confirm the diagnosis of liver damage (Pratt and Kaplan 2000). Our study presented high ALT and AST activities in diabetic groups. The B. holophylla treatment also caused increased activities of these enzymes, suggesting this plant led to a liver injury. This finding in association with the decreased body weight reinforce the possible toxic effect of the plant in an impaired organism by diabetes.

In conclusion, the treatment with aqueous extract of $B$. holophylla leaves given to diabetic rats presented no hypoglycemic effect in nondiabetic animals and no antidiabetic effect in diabetic animals with the doses studied. In addition, the diabetic animals treated with the $B$. holophylla extract caused inconvenient effects and its indiscriminate consumption requires particular carefulness.

\section{ACKNOWLEDGMENTS}

The authors are grateful to Thais Leal Silva and Jeferson José Silva Sousa, undergraduate students of the Institute of Biological and Health Sciences UFMT, for technical assistance.

\section{REFERENCES}

ABU-LEBDEH HS AND NAIR KS. 1996. Protein metabolism in diabetes mellitus. Baillières Clin Endocrinol Metab 4: 589-601.

ADA - AMERICAN DIABETES ASSOCIATION. 2016 Diagnosis and classification of diabetes mellitus. Diabetes Care 39: S13-S22.

CAMPOS KE, BALBI APC AND ALVES MJQF. 2009. Diuretic and hipotensor activity of aqueous extract of parsely seeds (Petroselium sativum) in rats. Rev Bras Farmacogn 19(1A): 41-45.

CAMPOS KE, SINZATO YK, PIMENTA WP, RUDGE MVC AND DAMASCENO DC. 2007. Effect of maternal obesity on diabetes development in adult rat offspring. Life Sci 81(19): 1473-1478.

CECHINEL FILHO V. 2009. Chemical composition and biological potential of plants from the Genus Bauhinia. Phytother Res 23: 1347-1354.

COOPPAN R. 2005. General approach to the treatment of Diabetes mellitus. In: Kahn CR, Weir GC, King GL, Jacobson AM, Moses AC and Smith RT (Eds), Joslin's Diabetes mellitus. Lippincott Williams \& Wilkans, Philadelphia, p. 587-596.

DAMASCENO DC, SILVA HP, VAZ GF, VASQUES-SILVA FA, CALDERON IMP, RUDGE MVC, CAMPOS KE AND VOLPATO GT. 2012. Diabetic rats exercised prior to and during pregnancy: maternal reproductive outcome, biochemical profile, and frequency of fetal anomalies. Reprod Sci 20: 730-738.

DAMASCENO DC AND VOLPATO GT. 2008. Antidiabetic botanical extracts. In: In: Watson RR and Preedy VR (Eds), Botanical Medicine in Clinical Practice. CAB International, London, p. 547-551.

DONATO AM. 1995. Anatomia foliar e abordagem fitoquímica de Bauhinia forficata Link. Bradea 6: 357-371.

FRANKISH N, DE SOUSA MF, MILLS C AND SHERIDAN H. 2010. Enhancement of insulin release from the beta-cell line INS-1 by an ethanolic extract of Bauhinia variegata and its major constituent roseoside. Planta Med 76: 995 997.

GÖBL CS, BRANNATH W, BOZKURT L, HANDISURYA A, ANDERWALD C, LUGER A, KREBS M, KAUTZKYWILLER A AND BISCHOF MG. 2010. Sex-specific differences in glycemic control and cardiovascular risk 
factors in older patients with insulin-treated type 2 diabetes mellitus. Gend Med 7: 593-599.

KAHN CR, WEIR GC, KING GL, JACOBSON AM, MOSES AC AND SMITH RT. 2005. Joslin's Diabetes mellitus. 4. ed. Philadelphia: Lippincott Williams \& Wilkans, p. 1209.

KIM W, PEEVER TL, PARK JJ, PARK CM, GANG DR, XIAN M, DAVIDSON JA, INFANTINO A, KAISER WJ AND CHEN W. 2016. Use of metabolomics for the chemotaxonomy of legume-associated Ascochyta and allied genera. Sci Rep 6: 20192.

KISS ACI, TAKAKU M, DAMASCENO DC, CAMPOS KE, SINZATO YK, LIMA PO AND VOLPATO GT. 2006. Efeito do extrato aquoso de Allium sativum L. sobre parâmetros bioquímicos de ratas com diabete induzido por Streptozotocin. Rev Bras Plantas Med 8: 24-30.

KNOPFHOLZ J ET AL. 2014. Validation of the Friedewald formula in patients with metabolic syndrome. Cholesterol 2014: 1-5.

LINO CS, DIÓGENES JP, PEREIRA BA, FARIA RA, ANDRADE NETO M, ALVES RS, QUEIROZ MG, SOUSA FC AND VIANA GS. 2004. Antidiabetic activity of Bauhinia forficata extracts in alloxan-diabetic rats. Biol Pharm Bull 27: 125-127.

LORENZI H AND MATOS FJA. 2002. Plantas medicinais no Brasil: nativas e exóticas cultivadas. Nova Odessa, Instituto Plantarum.

MASCARENHAS-MELO F, MARADO D, PALAVRA F, SERENO J, COELHO Á, PINTO R, TEIXEIRA-LEMOS E, TEIXEIRA F AND REIS F. 2013. Diabetes abrogates sex differences and aggravates cardiometabolic risk in postmenopausal women. Cardiovasc Diabetol 12: 61.

MELLO MAR, SOUZA T, BRAGA LR, SANTOS W, RIBEIRO IA AND GOBATTO CA. 2001. Glucose tolerance and insulin action in monosodium glutamate (MSG) obese exercise-trained rats. Physiol Chem Phys Med 33(1): 63-71.

PEPATO MT, BAVIERA AM, VENDRAMINI RC AND BRUNETTI IL. 2004. Evaluation of toxicity after 1-month treatment with Bauhinia forficata decoction in streptozotocin-induced diabetic rats. BMC Complement Altern Med 4: 1-8.

PEPATO MT, KELLER EH, BAVIERA AM, KETTELHUT IC, VENDRAMINI RC AND BRUNETTI IL. 2002. Antidiabetic activity of Bauhinia forficata decoction in streptozotocin-diabetic rats. J Ethnopharmacol 81: 191-197.

PINHEIRO TS, JOHANSSON LA, PIZZOLATTI MG AND BIAVATTI MW. 2006. Comparative assessment of kaempferitrin from medicinal extracts of Bauhinia forficata Link. J Pharm Biomed Anal 41: 431-436.

POWERS AC AND D'ALESSIO D. 2011. Endocrine Pancreas and Pharmacotherapy of Diabetes Mellitus and Hypoglycemia. In: Brunton LL, Chabner BA, Knollmann BC, Goodman \& Gilman. The Pharmacological Basis of
Therapeutics. $12^{\text {th }}$ ed., New York: McGraw-Hill, p. 1237 1273.

PRATT DS AND KAPLAN MM. 2000. Evaluation of abnormal liver-enzyme results in asymptomatic patients. N Engl J Med 342: 1266-1271.

REECE EA, COUSTAN DR AND GABBE SG. 2004. Diabetes in Women: Adolescence, Pregnancy and Menopause. Lippincott Williams \& Wilkins, New York, NY.

ROZZA AL, CESAR DAS, PIERONI LG, SALDANHA LL, DOKKEDAL AL, DE-FARIA FM, SOUZA-BRITO ARM, VILEGAS W, TAKAHIRA RK AND PELLIZZON CH. 2015. Antiulcerogenic activity and toxicity of Bauhinia holophylla hydroalcoholic extract. Evid Based Complement Alternat Med 2015: 439506.

SENGUPTA P. 2013. The laboratory rat: Relating its age with human's. Int J Prev Med 4: 624-630.

SILVA FRMB, SZPOGANICZ B, PIZZOLATTI MG, WILLRICH MA AND DE SOUSA E. 2002. Acute effect of Bauhinia forficata on serum glucose levels in normal and alloxan-induced diabetic rats. J Ethnopharmacol 83: 33-37.

SINZATO YK, VOLPATO GT, IESSI IL, BUENO A, CALDERON IMP, RUDGE MV AND DAMASCENO DC. 2012. Neonatally induced mild diabetes in rats and its effect on maternal, placental, and fetal parameters. Exp Diabetes Res 2012: 108163.

TAI MM. 1994. A mathematical model for the determination of total area under glucose tolerance and other metabolic curves. Diabetes Care 17(2): 152-154.

TANCREDE G, ROUSSEAU-MIGNERON S AND NADEAU A. 1983. Long-term changes in the diabetic state induced by different doses of streptozotocin in rats. Br J Exp Pathol 64: 117-123.

TURNER B, MOLGAARD C AND MARCKMANN P. 2004. Effect of garlic (Allium sativum) powder tablets on serum lipids, blood pressure and arterial stiffness in normolipiademic volunteers: a randomized, double-blind placebo controlled trial. Br J Nutr 92: 701-706.

UMRANI DN AND GOYAL RK. 2002. Beneficial effects of fenoldopan treatment on renal function in streptozotocin induced diabetic rats. Clin Exp Hypertens 135(4): 539547.

VOLPATO GT, CALDERON IMP, SINZATO S, CAMPOS KE, RUDGE MV AND DAMASCENO DC. 2011. Effect of Morus nigra aqueous extract treatment on the maternalfetal outcome, oxidative stress status and lipid profile of streptozotocin-induced diabetic rats. J Ethnopharmacol 138: 691-696.

VOLPATO GT, DAMASCENO DC, CALDERON IMP AND RUDGE MVC. 1999. Estudo do extrato de Bauhinia forficata L. sobre o diabete em ratas prenhes. Rev Bras Plantas Med 2: 49-55.

VOLPATO GT, DAMASCENO DC, CALDERON IMP AND RUDGE MVC. 2002. Revisão de plantas brasileiras 
com comprovado efeito hipoglicemiante no controle do Diabetes mellitus. Rev Bras Plantas Med 4: 35-45.

VOLPATO GT, DAMASCENO DC, RUDGE MV, PADOVANI CR AND CALDERON IMP. 2008. Effect of Bauhinia forficata aqueous extract on the maternal-fetal outcome and oxidative stress biomarkers of streptozotocin-induced diabetic rats. J Ethnopharmacol 116: 131-137.
VOLPATO GT, VIEIRA FL, DAMASCENO DC, CÂMARA FLA, DI STASI LC AND LEMONICA IP. 2007. Efeito do extrato aquoso de folhas de Polymnia sonchifolia (yacon) em ratas diabéticas. Rev Bras Plantas Med 9(2): 88-93.

YOUNG DS. 2000. Effects of Drugs on Clinical Laboratory Tests. 4. ed. Washington, DC: AACC Press. 